\title{
WHAT ROLE SHOULD PUBLIC OPINION PLAY IN ETHICO-LEGAL DECISION \\ MAKING?: THE EXAMPLE OF SELECTING SEX FOR NON-MEDICAL REASONS USING PREIMPLANTATION GENETIC DIAGNOSIS
}

Summary

In this article we consider the prohibition on the use of preimplantation genetic diagnosis to select an embryo on the basis of its sex for non-medical reasons. We use this as a case study to explore the role that public consultations have and should play in ethico-legal decision making. Until the Human Fertilisation and Embryology Act 1990 was amended by the Human Fertilisation and Embryology Act 2008, non-medical sex selection of an embryo was not statutorily regulated but it was the policy of the Human Fertilisation and Embryology Authority that such selection should not occur. However, since 2009 it has been a criminal offence to select an embryo on the basis of its sex for non-medical reasons. We consider the reasons given for this change and explore the role that 'public opinion' had in the decisionmaking process. On the face of it, asking the public what they think seems reasonable, fair and democratic, and those who are not in favour of public consultations being accorded great weight in matters of policy may appear out of touch and as wanting to impose their moral views on the public at large. But there are problems with doing so, especially when seeking to regulate ethically controversial issues. We discuss whether regulation should be influenced by public opinion obtained via 'public consultations', and utilise sex selection for non-medical reasons as an example of how (apparently) public opinion was used to support the criminalisation of this practice.

Key words - criminalisation, harm principle, preimplantation genetic diagnosis, public opinion, sex selection, welfare of the child 


\section{INTRODUCTION}

Folklore around how to conceive a child of a particular sex is widespread and ultrasounds can be used to detect the sex of a foetus at about 20 weeks gestation. However, it was not until the end of the 1980s that technology advanced so that an embryo could be tested and its sex identified at a very early stage in its development. In 1989 it was reported that researchers in England had successfully used preimplantation genetic diagnosis (PGD) to identify the sex of an embryo, ${ }^{1}$ and three years later it was reported that a 'normal girl' had been born following in vitro fertilisation (IVF) and PGD testing for cystic fibrosis. ${ }^{2}$ Embryos created via IVF can undergo PGD when the embryo is about two to three days in development and consists of about eight cells. One or two cells are removed from the embryo and these can be tested to detect a genetic condition. ${ }^{3}$ Neither IVF nor PGD were statutorily regulated in 1989 and while IVF was subsequently regulated by the original Human Fertilisation and Embryology Act 1990, using PGD in the treatment context was not. Thus, between 1991 (when the original 1990 Act came into force) and 2009 (when the amendments introduced to that Act by the Human Fertilisation and Embryology Act 2008 came into force) guidance on using PGD was only provided by the Human Fertilisation and Embryology Authority (HFEA) in its nonlegally binding Code of Practice. This has now changed. Under the amended 1990 Act PGD may be used in certain circumstances, including to identify the sex of an embryo, if the HFEA has granted a licence to the clinic for this, and then only for medical reasons. ${ }^{4}$

\footnotetext{
1 AH Handyside and others, 'Biopsy of human preimplantation embryos and sexing by DNA amplification' (1989) 333 Lancet 347.

2 AH Handyside and others, 'Birth of a normal girl after in vitro fertilization and preimplantation diagnostic testing for cystic fibrosis’ (1992) 327 New England Journal of Medicine 905, 905.

${ }^{3}$ See HFEA, 'Pre-implantation Genetic Diagnosis (PGD)' (2014) <http://www.hfea.gov.uk/preimplantationgenetic-diagnosis.html> accessed 17/11/15.

1990 Act, ss 3(1)-(1A), 11, and Sched 2, paras 1ZA-B. All references are to the 1990 Act as amended by the Human Fertilisation and Embryology Act 2008 unless stated otherwise.
} 
Notably, it is now a criminal offence to perform PGD without a licence, outside the terms of a licence, or use to it to select an embryo on the basis of its sex for non-medical reasons. ${ }^{5}$ Therefore, while some of the amendments introduced by the 2008 Act have been viewed (by some) as (unduly) permissive and liberal, such as those relating to section 13(5) and the concept of the welfare of the child, reproductive choice has not been expanded for all. Previously the HFEA could have altered its position and permitted non-medical sex selection under its Code of Practice. Now any such changes will require legislative action, with all the difficulties that follow from this. We acknowledge that it could be seen as 'dangerous' for controversial questions to be dealt with away from Parliament, but our focus here is not on the role of Parliament or other bodies in this regard per se. Rather, we are concerned with the use of 'public opinion' to support the prohibition of specific practices, with sex selection for non-medical reasons our example.

We are interested in how and why it was decided that it was necessary and appropriate that it should be illegal to use PGD to select an embryo on the basis of its sex on non-medical grounds. ${ }^{6}$ The HFEA has authorised PGD in the UK for over 100 inherited conditions, ${ }^{7}$ thereby allowing parents to test for inherited disorders and implant embryos that are not affected by those genetic traits. PGD can also be used to identify the sex of an embryo and this might occur for medical or non-medical reasons. PGD can be used to identify usually female embryos in order to implant them to avoid certain sex linked genetic disorders, such as Duchenne muscular dystrophy and haemophilia A and B. Females may carry sex linked

\footnotetext{
51990 Act, s 41(2).

${ }^{6}$ We are not interested here in the ethics of PGD per se. For discussion on this see, for eg., S Wilkinson and E Garrard, Eugenics and the Ethics of Selective Reproduction (Keele University: Keele, 2013); D King, 'Preimplantation genetic diagnosis and the "new eugenics' (1999) 25 Journal of Medical Ethics 176; C Gavaghan, 'Right problem wrong solution: A pro-choice response to "expressivist" concerns about preimplantation genetic diagnosis’ (2007) 16 Cambridge Quarterly of Healthcare Ethics 20.

${ }_{7}^{7}$ For a list of the conditions that can be tested for see HFEA, 'PGD conditions licensed by the HFEA' (2015): $<$ http://www.hfea.gov.uk/cps/hfea/gen/pgd-screening.htm> accessed 17/11/15.
} 
disorders but they rarely inherit two copies of the gene responsible and so are unlikely to suffer from these diseases, but males only need to inherit one affected gene to inherit the disease and they have a $50 \%$ chance of doing so if their genetic mother is a carrier of the gene. In other cases, such as Fragile X syndrome, conditions are more severely expressed in one sex than the other. Thus, if only female embryos are implanted the risk of producing a child with these disorders can be avoided. In contrast, an embryo's sex might be identified for non-medical reasons because the would-be parents have a preference for a child of that sex. Using PGD to select female embryos to implant to avoid a child being born with a sex related genetic disorder is legally acceptable, ${ }^{8}$ and usually deemed morally acceptable if not desirable, ${ }^{9}$ but selecting an embryo on the basis of its sex for non-medical reasons is more controversial, ${ }^{10}$ and is now punishable by two years imprisonment, a fine or both. ${ }^{11}$

In Part II we consider the regulation of sex selection for non-medical reasons and then examine the basis for prohibiting this use of PGD in Part III, before exploring problems with using public opinion as a basis for regulation in Part IV. We argue that while there appears to be agreement that the State should, and needs to, take a stance on ethically controversial issues in order to draw a clear line between what is legally permitted and prohibited in areas where personal opinions are strongly held, policy makers and legislators are increasingly faced with difficult decisions about how to regulate such issues in areas where debate is polarised and there is little chance of consensus. We suggest that a position must be taken

\footnotetext{
${ }_{9}^{8}$ Permitted under 1990 Act, Sched 2, para 1ZA.

${ }^{9}$ Ethics Committee of the American Society for Reproductive Medicine, 'Use of preimplantation genetic diagnosis for serious adult onset conditions: A committee opinion’ (2013) 100 Fertility and Sterility 54; JA Robertson, 'Extending preimplantation genetic diagnosis: Medical and non-medical uses' (2003) 29 Journal of Medical Ethics 213.

${ }^{10}$ For contrary views see, for eg., JA Robertson and T Hickman, 'Should PGD be used for elective gender selection?: A discussion of the ethics of the use of gender selection for nonmedical reasons' (2013) Contemporary $\mathrm{OB} / G Y N<\mathrm{http}: / /$ contemporaryobgyn.modernmedicine.com/contemporary-obgyn/news/shouldpgd-be-used-elective-gender-selection> accessed 17/11/15.

${ }^{11} 1990$ Act, ss 3(1)-(1A), 11, 41(2), and Sched 2, paras 1ZA-B.
} 
that can be defended as the most reasonable solution to a particular ethical problem and, in Part V, we question whether reliance on public opinion can and should aid in this regard.

\section{THE REGULATION OF SEX SELECTION FOR NON-MEDICAL REASONS}

When PGD was first successfully used in the UK it was not statutorily regulated, despite the fact that the possibility of sex selection and testing an embryo had been recognised by the Warnock Committee in their 1984 Report. ${ }^{12}$ They commented that '[w]e see no reason why, if a method of selecting the sex of a child before fertilisation is developed, this should not be offered to couples who have good medical reasons for choosing the sex of their child' ${ }^{13}$ While the original 1990 Act addressed using PGD in the research context and a research licence could be granted in order to develop methods 'for detecting the presence of gene or chromosome abnormalities in embryos before implantation', ${ }^{14}$ it did not expressly state that a treatment licence could authorise the clinical use of PGD. ${ }^{15}$ In 1993 the HFEA declared that PGD could be used to identify the sex of an embryo for medical reasons, ${ }^{16}$ and the third edition of its Code of Practice, in 1995, was the first to include anything on selecting an embryo on the basis of its sex. It stated that '[c]entres should not select the sex of embryos for social reasons', ${ }^{17}$ and this provision has been included in every subsequent $\underline{\text { Code. }}{ }^{18}$ A

\footnotetext{
${ }^{12}$ Department of Health and Social Security, Report of the Committee of Inquiry into Human Fertilisation and Embryology (1984) Cmnd. 9314, Ch 9 (Warnock Report).

${ }^{13}$ Warnock Report, n 12 above, para 9.11, emphasis supplied.

${ }^{14}$ Original 1990 Act, Sched 2, para 3(2)(e).

${ }^{15}$ Original 1990 Act, s 11, Sched 2, para 1. For a history of the regulation of PGD in the UK see E Jackson, 'Statutory Regulation of PGD in the UK: Unintended Consequences and Future Challenges' in SAM McLean and S Elliston (eds) Regulating Pre-implantation Genetic Diagnosis: A Comparative and Theoretical Analysis (Routledge: Oxford, 2013).

${ }^{16}$ Human Fertilisation and Embryology Authority (HFEA), Sex Selection Public Consultation Document (HFEA: London, 1993) paras 17 and 42.

${ }^{17}$ HFEA, Code of Practice (HFEA: London, $3^{\text {rd }}$ edn, 1995) para 7.20.

${ }^{18}$ Subsequently, HFEA, Code of Practice (HFEA: London, $4^{\text {th }}$ edn, 1998) para 7.20; HFEA, Code of Practice (HFEA: London, $5^{\text {th }}$ edn, 2001) para 9.9; HFEA, Code of Practice (HFEA: London, $6^{\text {th }}$ edn, 2003) paras 8.9, 14.10, Appendix H - p 159; HFEA, Code of Practice (HFEA: London, $7^{\text {th }}$ edn R4, 2008) G.8.7.1, Appendix A A.13.7, A.13.9, A.13.11; HFEA, Code of Practice (HFEA: London, $8^{\text {th }}$ edn R8, 2015) paras 9B, T88, 10D. The prohibition on using sperm sorting for sex selection purposes has similarly been prohibited: HFEA, Code, $4^{\text {th }}$
} 
framework for and guidance on the use of PGD was included in the sixth edition of the Code, in 2003, which covered matters such as licensing, genetic counselling, patient information and clinical decision-making, including the s 13(5) obligation to consider the welfare of the child. $^{19}$ But the Code is not legally binding and it is not a criminal offence to breach it, although a licence committee can take any breaches of it into account when deciding whether to vary or revoke a licence. ${ }^{20}$ With regard to 'formal' regulation, in 2005 the House of Lords confirmed that PGD fell within the HFEA's licensing jurisdiction, ${ }^{21}$ and Regulations were introduced in 2007 to amend the original 1990 Act to make it clear that a licence from the HFEA could authorise 'procuring, keeping, testing, processing or distributing embryos'.22 Thus, from 1991 (when the 1990 Act came into force) until 2007 neither PGD nor sex selection were formally regulated. While it was the HFEA's policy not to license the use of PGD to select an embryo of a particular sex for non-medical reasons, it was not illegal to do so. $^{23}$

Concern about the regulation of human fertilisation and embryology generally was growing during the 2000s and there was a sense that the science was developing at a pace which was outstripping the regulatory framework. During 2005 the House of Commons Science and Technology Committee published a report on human reproduction, which included sex

edn, para 7.21 (any reason); HFEA, Code, $5^{\text {th }}$ edn, para 9.10 (any reason); HFEA, Code, $7^{\text {th }}$ edn, G.8.7.2 (any reason). However, the most recent Code permits sperm sorting for medical reasons provided the patient receives information about the 'process, procedures, possible risks and the experience of the clinic in doing the procedure' (HFEA, Code, $8^{\text {th }}$ edn, para 10.20), but gradient methods should not be used for medical reasons because of the technique's unreliability (para.10.19).

${ }^{19}$ HFEA, Code, $6^{\text {th }}$ edn, n 18 above, Part 14. Subsequently, HFEA, Code, $7^{\text {th }}$ edn, $n 18$ above, G.12, Appendix A A.13.7-A13.9; HFEA, Code, $8^{\text {th }}$ edn, n 18 above, Sections 9-10.

${ }^{20} 1990$ Act, s 25.

${ }^{21}$ R (Josephine Quintavalle) v. HFEA [2005] UKHL 28, [35] per Lord Hoffman; [62] per Lord Brown.

${ }^{22}$ Under Human Fertilisation and Embryology (Quality and Safety Regulations) 2007/1522, para 29.

${ }^{23}$ Note that selecting an embryo on the basis of its sex for 'social reasons' is prohibited under Article 14 of the European Convention on Human Rights and Biomedicine 1997. This Convention has not been signed or ratified by the UK. 
selection, ${ }^{24}$ and in its response the Government adopted and endorsed the position in the HFEA's Code of Practice that licensed clinics may not use information derived from tests on an embryo or material removed from it to select embryos of a particular sex for non-medical reasons. $^{25}$ The Department of Health conducted a review of and public consultation on the 1990 Act in 2005, including the use and regulation of sex selection. ${ }^{26}$ A White Paper was published in December 2006 in which it was said that 'the Government believes that there is a general desire for the law to be clearer on [screening and selecting embryos], and hence for Parliament to define some limits or criteria that apply to testing of embryos' ${ }^{27}$ In May 2007 a draft bill was published which included a statutory prohibition on selecting an embryo on the basis of sex for non-medical reasons, ${ }^{28}$ and a Joint Parliamentary Committee was appointed to scrutinise it. The Committee recommended that sex selection for non-medical reasons was not permitted, was concerned that the wording in the draft bill was more restrictive than current HFEA policy, and recommended that the bill was amended in line with that policy. ${ }^{29}$ The Government accepted that recommendation, ${ }^{30}$ the Human Fertilisation and Embryology Bill (the HFE Bill) was amended accordingly and was introduced into the House of Lords in November 2007, with the prohibition on selecting sex for non-medical reasons one of the main provisions. ${ }^{31}$

\footnotetext{
${ }^{24}$ House of Commons Science and Technology Committee, Human Reproductive Technology and the Law, Fifth Report of Session 2004-05 (2005), Volume I, HC 7-1, paras 131-142.

${ }^{25}$ HM Government, Human Reproductive Technologies and the Law: Government Response to the Report from the House of Commons Science and Technology Committee (2005) Cm 6641, para 45, response to Recommendations 29 and 30. The Code applicable at the time was HFEA, Code, $6^{\text {th }}$ edn, n 18 above, para 14.10.

${ }^{26}$ Department of Health (DH), Review of the Human Fertilisation and Embryology Act: A Public Consultation (DH: London, 2005).

${ }^{27}$ DH, Review of the Human Fertilisation and Embryology Act: Proposals for revised legislation (including establishment of the Regulatory Authority for Tissue and Embryos), Cm 6989 (2006) para. 2.42.

${ }^{28}$ Human Tissue and Embryos (Draft) Bill, Cm 7087, Sched 2 para 1ZB.

29 Joint Committee on the Human Tissue and Embryos (Draft) Bill, First Report (2007) paras 204-205: <http://www.publications.parliament.uk/pa/jt200607/jtselect/jtembryos/169/16902.htm> accessed 18/11/15. Also, paras 200-203. For the Code at that time see HFE.A, Code, $6^{\text {th }}$ edn, n 18 above, Part 14

${ }^{30}$ Government Response to the Report from the Joint Committee on the Human Tissue and Embryos (Draft) Bill, Cm 7209 (TSO 2007) Recommendation 18 and paras 44-45.

${ }^{31}$ HL Deb 19 November 2007, cols 665-667.
} 
The Human Fertilisation and Embryology Act 2008 received Royal Assent in November 2008 and the amendments to the 1990 Act came into force on 1 October 2009. PGD in both the research and treatment contexts can now only be performed under a licence from the HFEA, a licence can only authorise embryo testing for certain purposes, and PGD can only be licensed to identify an embryo's sex for medical purposes. ${ }^{32}$ The HFEA can only issue a treatment licence which authorises testing an embryo ${ }^{33}$ (a) to establish whether an embryo has an abnormality which might affect its ability to result in a live birth, (b) where there is a 'particular risk' that an embryo might have an abnormality to establish whether it has it, or (c) where there is a 'particular risk' that any resulting child will have or develop a genderrelated 'serious physical or mental disability', 'serious medical illness', or 'serious medical condition'. ${ }^{34}$ A licence can only authorise testing embryos under (b) if the HFEA is satisfied that there is a 'significant risk' that the resulting child will have or develop a 'serious physical or mental disability, illness or any other serious medical condition', ${ }^{35}$ and with regards to (c), a physical or mental disability, illness or condition is gender-related if the HFEA is satisfied that '(a) it affects only one sex or (b) affects one sex significantly more than other' ${ }^{36}$

Since the sixth edition of the HFEA's Code of Practice the meanings of 'significant risk' and 'serious' have been deemed to be matters for those seeking treatment and their treatment team, with factors listed for consideration when determining the appropriateness of using

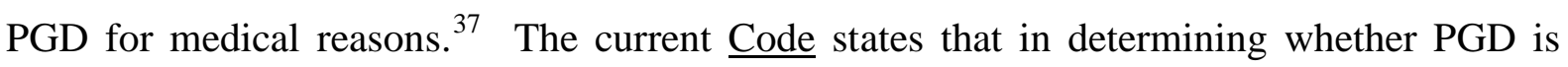
appropriate in a particular case the centre should consider:

\footnotetext{
${ }^{32}$ See $n 3$ above.

331990 Act, Sched 2, para 1(1)(b).

341990 Act, Sched 2, para 1ZA(1).

351990 Act, Sched 2, para 1ZA(2).

${ }^{36} 1990$ Act, Sched 2, para 1ZA(3).

${ }^{37}$ HFEA, Code, 6 ${ }^{\text {th }}$ edn, n 18 above, paras 14.22-14.23; HFEA, Code, $7^{\text {th }}$ edn, n 18 above, paras G.12.3.2G.12.3.3; HFEA, Code, $8^{\text {th }}$ edn, n 18 above, paras 10.5-10.7. On determining the seriousness of a disease see, for example, R Scott, C Williams, K Ehrich, and B Farsides, 'The appropriate extent of preimplantation genetic diagnosis: Health professionals' and scientists' view on the requirement for a significant risk of a serious genetic
} 
(a) the views of the people seeking treatment in relation to the condition to be avoided, including their previous reproductive experience

(b) the likely degree of suffering associated with the condition

(c) the availability of effective therapy, now and in the future

(d) the speed of degeneration in progressive disorders

(e) the extent of any intellectual impairment

(f) the social support available, and

(g) the family circumstances of the people seeking treatment. ${ }^{38}$

\section{WHY PROHIBIT NON-MEDICAL SEX SELECTION?}

In just under 15 years the regulation of sex selection for non-medical reasons has shifted from guidance that clinics 'must not', 39 'are expected not to', ${ }^{40}$ or 'should not' ${ }^{41}$ perform it, to a criminal prohibition on using PGD for these reasons. This change merits investigation because, in general, the 2008 Act's amendments to the original 1990 Act were more permissive in nature, including removing the requirement to consider the child's need for a father and introducing, in essence, a presumption to treat unless 'significant harm or neglect' is predicted. $^{42}$ In contrast, using PGD to identify an embryo's sex for non-medical reasons was subject to more prohibitive treatment. While the amended 1990 Act removed many obstacles to access to other controversial procedures, such as the use of PGD to create

condition’ (2007) 15 Medical Law Review 320; S Holm, ‘Ethical Issues in Preimplantation Diagnosis’ in J Harris and S Holm (eds.) The Future of Human Reproduction (Oxford University Press: Oxford, 1998).

${ }^{38}$ HFEA, Code, $8^{\text {th }}$ edn, $n 18$ above, para 10.7.

${ }^{39}$ HFEA, Code, $3^{\text {rd }}$ edn, n 17 above, para 7.20; HFEA, Code, $4^{\text {th }}$ edn, $n 18$ above, para 7.20; HFEA, Code, $5^{\text {th }}$ edn, n 18 above, para 9.9.

${ }^{40}$ HFEA, Code, $6^{\text {th }}$ edn, $n 18$ above, para 8.9.

${ }^{41}$ HFEA, Code, $7^{\text {th }}$ edn, $n 18$ above, G.8.7.1; HFEA, Code, $8^{\text {th }}$ edn, $n 18$ above, 9B and $10 \mathrm{D}$.

421990 Act, s 13(5); HFEA, Code $8^{\text {th }}$ edn, n 18 above, paras 8.3, 8.10, 8.11, 8.15, respectively. 
'saviour siblings', non-medical sex selection was criminalised. This appears to have been based on notions of harm and the welfare of the child, and public opinion in support of a prohibition. We say 'appears' because the reasons for putting into legislation the HFEA's policy prohibiting sex selection for non-medical reasons are not clear, even though Lord Darzi, the supporter of the HFE Bill in the House of Lords, said that doing so would 'giv[e] Parliament the opportunity to fully debate the provisions' ${ }^{43}$ It might thus be thought that debates on the relevant clause would have been extensive, yet a search of Hansard reveals otherwise and there was, in fact, minimal discussion of sex selection for non-medical reasons in both Houses, perhaps because it was believed to be obvious that its prohibition was both necessary and appropriate. Rather, statements merely supporting the provision were common. $^{44}$

\section{A. The harm principle and the welfare of the child}

For societies which value respect for individual autonomy, the harm principle is a central principle that guides the making of law. Under this principle, 'the only purpose for which power can be rightfully exercised over any member of a civilized community, against his will, is to prevent harm to others', and 'the conduct from which it is desired to deter him, must be calculated to produce evil to some one else' [sic]. ${ }^{45}$ Thus, if we are to respect the autonomous choices of individuals and allow them to have as much control over their lives as possible, their choices should only be curtailed where this is necessary to prevent serious harm to others. Many of the provisions of the original 1990 Act and some of the amendments to that Act introduced by the 2008 Act, were clearly guided by this liberal presumption of avoidance of serious harm. For example, section 13(5) of both Acts emphasise the need to

\footnotetext{
${ }^{43}$ HL Deb 19 November 2007, col 666, Lord Darzi.

44 See, for eg., HL Debs 21 November 2007, col 844, Lord Ahmed; 3 December 2007, col 1598, Lord Alton; HC Debs 12 May 2008, col 1147, David Arness; 19 May 2008, col 101, Mark Simmonds.

45 JS Mill, On Liberty and Other Essays, (Oxford University Press: Oxford, 2008) 14, emphasis supplied.
} 
consider the welfare of children born as a result of any treatment provided under them, and the Science and Technology Committee noted that the HFEA had used a 'welfare argument' to support their recommendation that sex selection for non-medical reasons should not be permitted. ${ }^{46}$ Thus, the HFEA stated that:

the most persuasive arguments for restricting sex selection technologies, besides the potential health risks involved, are related to the welfare of the children and families concerned ... that children selected for their sex alone may in some way be psychologically damaged by the knowledge that they had been selected in this way as embryos. $^{47}$

Furthermore, '[i]n reaching a decision we have been particularly influenced by the considerations ... relating to the possible effects of sex selection for non-medical reasons on the welfare of the child born as a result, and by [public opinion]' ${ }^{48}$ We discuss the later in Section B below.

In earlier editions of the HFEA's Code of Practice, the legal requirement to consider the welfare of children was consistently interpreted to include subjective factors such as the potential parents' ‘commitment to raise children', their 'ability to provide a stable and supportive environment for a child/children', and their 'age, health and ability to provide for the needs of a child/children'. ${ }^{49}$ A high threshold of welfare was thus suggested and anything

\footnotetext{
${ }^{46}$ House of Commons, n 24 above, para 272.

${ }^{47}$ HFEA, Sex Selection: Options for Regulation - A report on the HFEA's 2002-3 review of sex selection including a discussion of legislative and regulatory options (HFEA: London, 2003), para 139, emphasis supplied.

${ }^{48}$ HFEA, n 47 above, para 147, emphasis supplied.

${ }^{49}$ HFEA, Code, $6^{\text {th }}$ edn, n 18 above, para 3.12. Previously, HFEA, Code, $5^{\text {th }}$ edn, $n 18$ above, para 3.13; HFEA, Code, $4^{\text {th }}$ edn, n 18 above, para 3.17; HFEA, Code, $3^{\text {rd }}$ edn, n 17 above, para 3.15; HFEA, Code of Practice (HFEA: London, $2^{\text {nd }}$ edn, 1993) para 3.16; HFEA, Code of Practice (HFEA: London, $1^{\text {st }}$ edn, 1991) para 3.14.
} 
less than optimal responses, whatever those might be, could result in a clinic being wary of providing treatment. Indeed, such welfare formulations led to some NHS clinics restricting access to fertility treatment to relatively young healthy women in established heterosexual relationships where there were no obvious risk factors such as genetic diseases or a history of abuse or neglect. $^{50}$ In 2005 the HFEA undertook a consultation with the public, patients, doctors and other professionals on welfare of the child considerations, ${ }^{51}$ which resulted in a move away from this reading of the welfare of the child provision as the HFEA concluded that:

there should be a presumption towards providing treatment to those who request it, but that treatment should be refused in cases where clinics conclude that the child to be born, or any existing child of the family, is likely to suffer serious harm. ${ }^{52}$

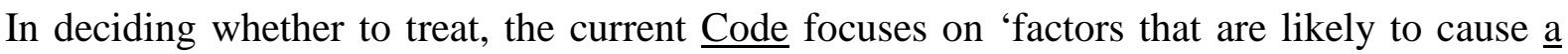
risk of significant harm or neglect to any child who may be born or to any existing child of the family'. ${ }^{53}$ These include any 'aspect' of their (and/or their partner's) 'past or current circumstances that may lead to any [existing or to-be born] child ... experiencing serious physical or psychological harm or neglect', referring to previous convictions relating to children, any child protection measures, or 'violence or serious discord in the family environment'. ${ }^{54}$ Past or current circumstances which might indicate an 'inability to care' for an existing child or one to-be-born will also be considered, including addiction problems,

\footnotetext{
${ }^{50} \mathrm{~N}$ Gamble, 'Considering the need for a father: The role of clinicians in safeguarding family values in UK fertility treatment' (2009) 19 Suppl. 1 Reproductive BioMedicine Online 15; R Bennett and J Harris, 'Restoring Natural Function: Access to Infertility Treatment Using Donate Gametes’ (1999) 2 Human Fertility 18.

${ }^{51}$ HFEA, Tomorrow's Children: A consultation on guidance to licensed fertility clinics on taking in account the welfare of children to be born of assisted conception treatment (HFEA: London, 2005).

${ }^{52}$ HFEA, Tomorrow's Children: Report of the Policy Review of Welfare of the Child Assessments in Licensed Assisted Conception Clinics (HFEA: London, 2006) 6, emphasis supplied.

${ }_{53}^{53}$ HFEA, Code, ${ }^{\text {th }}$ ed., $n 18$ above, para 8.10, emphasis supplied.

${ }^{54}$ Ibid, emphasis supplied.
} 
medical history, or 'circumstances that the centre considers likely to cause serious harm to any child mentioned above' ${ }^{55}$ Thus, apart from the latter factor, the Code now appears to focus decisions about whether particular individuals or couples should be provided with treatment on evidence that serious harm will befall existing or to-be-born children as a result of that treatment being provided.

In line with this general adherence to the harm principle as a guide to regulation in this area, in 2003 the HFEA stated that:

[t]he main argument against prohibiting sex selection for non-medical reasons is that it concerns that most intimate aspect of family life, the decision to have children. This is an area of private life in which people are generally best left to make their own choices and in which the State should intervene only to prevent the occurrence of serious harms, and only where this intervention is non-intrusive and likely to be effective. $^{56}$

Indeed, the HFEA is generally committed to the democratic or liberal presumption that individual choices, in this case reproductive choices, should only be interfered with in order to prevent serious harm to others, and many of the provisions of the amended 1990 Act reflect this. ${ }^{57}$ On this basis, it would seem that the only reason for prohibiting non-medical sex selection would be because it is thought to cause serious harm.

\footnotetext{
${ }^{55}$ Ibid, emphasis supplied.

${ }^{56}$ HFEA, n 47, para 132, emphasis supplied. For criticism of this report see, for eg., J Harris, 'Sex selection and regulated hatred’ (2005) 31 Journal of Medical Ethics 292; J Harris, ‘No sex selection please, we’re British’ (2005) 31 Journal of Medical Ethics 286; T Baldwin, 'Reproductive liberty and elitist contempt: Reply to John Harris’ (2005) 31 Journal of Medical Ethics 288.

${ }^{57}$ Harris, 'Sex selection', n 56 above.
} 


\section{Serious harm to the child-to-be-born}

Assessing the expected levels of harm an action is likely to cause existing children is often difficult but it is usually easier to quantify than assessments of harm to those who have yetto-be-born. There are two main ways of thinking about future lives and serious harm. First, there are lives that are sometimes called 'unworthwhile'. ${ }^{58}$ These are lives that we think are likely to be dominated by suffering and where negative experiences are likely to outweigh positive ones. Given this, life itself could be seen as a serious harm to this child as it brings overwhelming pain and suffering. Thus, we might consider bringing a child to birth in this condition a harm in itself. If it is this kind of serious harm that we are trying to avoid, we need to ask 'would existence itself be a serious harm or an overall negative experience for the resulting child?' If we consider existence generally to be a good thing and accept that most people will have a life they will value and want to continue, then such instances of not worthwhile lives will be rare and restricted to lives of extreme and unrelenting suffering. ${ }^{59} \mathrm{~A}$ second way of thinking about serious harm involves asking whether the future child is likely to suffer any foreseeable serious harm. The question is, 'is this child likely to suffer serious physical or psychological harm even if she is still likely to have a life that she will value?' We are not asking whether life itself would constitute a serious harm for the child born but whether its life would be compromised by what could be considered to be serious harm.

Historically, both ways of looking at harm and the welfare of the child were in evidence in the HFEA's Code of Practice and the legislation it was founded on. Thus, cases involving the first type of harm, where a life would be completely 'blighted' by suffering, would be clearcut cases of refusal of treatment and fairly rare. The more common discussions on the

\footnotetext{
${ }^{58}$ R Bennett, 'There can be no moral obligation to eradicate all disability' (2014) 23 Cambridge Quarterly of Healthcare Ethics 30, 31.

${ }^{59}$ R Bennett and J Harris, ‘Are There Lives Not Worth Living? When Is It Morally Wrong To Reproduce?’ in D Dickenson, (ed.) Ethical Issues in Maternal-Fetal Medicine (Cambridge University Press: Cambridge, 2002).
} 
welfare of the child would be whether this child is likely to suffer serious physical or psychological harm, although such harm would be unlikely to blight that life completely. As we have noted, considerations such as 'commitment to raise children', their 'ability to provide a stable and supportive environment for a child/children', and their 'age, health and ability to provide for the needs of a child/children', ${ }^{60}$ were considered important when assessing the likely welfare of the resultant child, even though failures to reach optimal levels of commitment, supportive environments or the health of the would-be parents would be unlikely to create a child who has a life we might consider not worth living or a harm in itself.

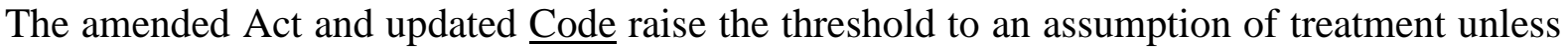
there is evidence that serious harm will befall the resultant child. However, it is still not clear that this consideration is restricted to only those rare cases where lives are likely to be completely blighted by suffering. Deciding which of these senses of serious harm should be adopted when considering the welfare of children born following assisted reproduction is important, but it is not our focus here. ${ }^{61}$ Instead, concern for the welfare of the future child on the basis of (serious) harm cannot be a reason to prohibit sex selection for non-medical reasons because there is no evidence that using PGD for these reasons will lead to either kind of serious harm to the welfare of the future child. Indeed, in its report on sex selection, the HFEA offered no evidence to support its conclusion that selection for non-medical reasons should be prohibited because of hypothetical risks to the welfare of a sex-selected child and its family, other than the concerns expressed in the public consultation, as we discuss in Section B below. ${ }^{62}$ Referring to this report and the HFEA's position, the Science and Technology Committee stated that 'the most persuasive argument was not that there was

\footnotetext{
${ }^{60}$ n 49 above.

${ }^{61}$ See further $n 59$ above.

${ }^{62}$ HFEA, n 47 above, para 139. Also, para 147.
} 
evidence of harm but that there was evidence of concern about harm. This is not a satisfactory use of evidence to support policy advice'. ${ }^{63}$ The Committee concluded that '[t]he onus should be on those who oppose sex selection for social reasons using PGD to show harm from its use', ${ }^{64}$ and that '[t]he UK should carefully consider the current evidence there [is] available now about [gender] imbalances and harms before allowing blanket changes [to] our laws and regulations on sex selection' ${ }^{65}$ Furthermore, it noted that '[t]he HFEA has drawn on theoretical psychosocial harms in formulating policy on sex selection, invoking the precautionary principle. It concerns us that the potential for harm is often quoted without recourse to a growing body of evidence of its absence, ${ }^{66}$

Without such evidence it is only possible to posit the harm that might be caused by using PGD to select an embryo on the basis of its sex for non-medical reasons, but not for medical reasons? It is possible that allowing parents to select to implant an embryo of a particular sex may cause the child some psychological difficulties or pressures as a result, but similar pressures that may be exerted on other children not selected in this way. It is hard to imagine these difficulties being so serious that they would cause the selected children harm, let alone harm so serious that it would obliterate the positive attributes that life has brought them. Parents who select the sex of their child in this way may be overbearing or have a particular idea of the sort of child they wish to have. Perhaps they want a child who will be a ballerina or a rugby player and hope that sex selection will help them reach this goal. However, many children have overbearing parents, parents who have strong ideas about how their children's lives should go and this may make us feel sorry for these children and try and remonstrate with their parents. But it is unlikely to make us feel that allowing these parents to create

\footnotetext{
${ }^{63}$ House of Commons, n 24 above, para 272, emphasis supplied.

${ }^{64}$ House of Commons, n 24 above, para 142, emphasis supplied. Also, Recommendation 30.

${ }^{65}$ House of Commons, n 24 above, para 140, emphasis supplied. Also, Recommendation 29.

${ }^{66}$ House of Commons, n 24 above, para 139, emphasis supplied.
} 
these children in this environment, in the only environment they could have been created, was a wicked and deplorable act. This is particularly as the children are as likely to value their lives as any other children. Indeed, children born as a result of using PGD to select sex for non-medical reasons may have what might be considered a sub-optimal life, but their life is as likely as any other to be one that they value overall. So, whatever view we take on what is meant by serious harm, it is difficult to see how a concern to protect future children from that harm can justify the prohibition on sex selection for non-medical reasons.

While children born as a result of using PGD to select sex for non-medical reasons may have what might considered to be a sub-optimal life, their life is as likely as any other to be one that they value overall. Indeed, it is difficult to understand how sex selection for non-medical reasons is likely to cause serious harm to the individual born as a result of this selection process. In fact, it is difficult to distinguish using PGD for these reasons from using PGD generally or for medical reasons with regard to avoiding serious harm and protecting the welfare of the resulting child, and also regarding the benefits they may produce. With regard to medical reasons, only a minority of cases will involve the avoidance of catastrophic disorder, a condition that is likely to completely blight that life and make it unworthwhile. Most cases of medical sex selection using PGD will be motivated by a desire to avoid serious disorders which are unlikely to render lives not worth living; for example, haemophilia, muscular dystrophy or Turner Syndrome. Thus, where medical sex selection is sanctioned, the choice may be between two worthwhile lives. If PGD is used to avoid a sex linked disorder and a child is born with a disorder that is unlikely to render her life unworthwhile, no child's welfare has been damaged. The affected child is born in the only state she can be born in and is likely to value her life as much as anyone else, albeit with physical and/or other complications that may require treatment. Medical sex selection does not 'save' anyone from 
living with a serious disorder. A different unaffected child is born as a result of PGD, rather than one individual being saved from this 'plight'. In most cases, using PGD for sex selection is not used to prevent serious harm to an identifiable individual but to allow prospective parents a chance to be a parent of the sort of child they wish to parent.

Thus, using PGD to identify an embryo's sex for medical reasons is not usually undertaken with the welfare of the child in mind. In most cases, we are not likely to affect the welfare of any individual child and we are not choosing between worthwhile lives. Instead, using PGD for medical reasons enables parents to have the child they want. The welfare of particular children is not affected by the choice between embryos, but the interests of the prospective parents may be better served if they are able to choose to be the parent of a child with less obstacles to overcome. The same is true with the benefits of using PGD to select sex for nonmedical reasons. In both cases parents wish to use PGD so that they can be a parent of a child with particular characteristics, and in both cases their choices do not, usually, have an impact on the welfare of the child-to-be.

In fact, taking this more widely, sex selection using PGD for non-medical reasons is in line with the general ethos of IVF and other assisted reproductive processes (such as surrogacy) more generally, which is to enable prospective parents to have a child with a particular characteristic - a genetic link to them. There are other options that would allow them to be a parent (such as adoption or sperm donation), but, in many cases, prospective parents prefer to have a child who is genetically related to one or both of them. It would, in fact, be more straightforward, cheaper and safer, for instance, to offer insemination with donated sperm instead of IVF using Intracytoplasmic Sperm Injection (ICSI), but we take the desire to have a genetically related child so seriously that we allow this use of resources and risk of some 
harm (all IVF involves some risk to the female partner as a result of hyperstimulation of the ovaries), ${ }^{67}$ in order to allow individuals a chance of parenting a child with the characteristics they want. So, some IVF is about having a child of a particular kind, not for medical reasons but because the parents want a child who has particular characteristics (genetically linked to them). Although some may think that this genetic link is not important, and we have evidence from adoption that it is possible to bond and have fulfilling relationships without this genetic link, when it comes to being a parent and having the desired parent-child relationship, this evidence does not change the fact that for many this link is important and will remain a relevant factor when they consider their reproductive choices. This is comparable with the case of sex selection for non-medical reasons. We can explain to people that we think that the sex of their child should not be important and that they should be prepared to parent a child of either gender, but this is unlikely to change their desire for a child of a particular sex.

In general, assisted reproduction allows individuals to parent the children they wish to including choosing the characteristics of those children. As the Department of Health has acknowledged, other forms of gamete and embryo selection are well-established and accepted within, for example, donor insemination, where the physical characteristics of the donor are selected so that any resulting child may resemble those receiving treatment. ${ }^{68}$ Within this general context of enabling choice regarding the children we can be parents to, sex selection for non-medical reasons does not seem so different in character or cost benefit analysis to that of other more generally acceptable assisted reproduction procedures. Given this, if the harm principle is to be used to justify the prohibition on non-medical sex selection then some other

\footnotetext{
${ }^{67}$ HFEA, 'IVF - The Risks' (2014) <http://www.hfea.gov.uk/ivf-side-effects.html> accessed 17/11/15.

${ }^{68} \mathrm{DH}$, above n 27, para 2.39 .
} 
kind of harm must be evoked. Might sex selection for non-medical reasons cause serious harm to society?

\section{Serious harm to society}

In one of the HFE Bill debates in the House of Lords, Baroness Williams said that:

There is so much at stake - so much money - in people, for example, being able to determine such things as the sex of their own child. Many noble Lords will know that the built-in hereditary preference for boys over girls has produced a surplus of what is estimated to be over 30 million young males in China, as against the women that they might one day marry. The social consequences of that are absolutely terrifying. They are the consequences of producing a warrior people - a warrior race if you like. We have to think about the social consequences. ${ }^{69}$

She suggested that the refusal to allow sex selection was one of three 'fragile dikes' (the others being embryo destruction after 14 days and the prohibition on cloning), and that:

If we are to remain in a civilised world - one that fully accepts the huge benefits of science but recognises that there are limits to what people should do in using other people for certain purposes - then these dikes must hold. We need all the help we can get in doing that. ${ }^{70}$

Similar comments were made in the 1984 Warnock Report where it was noted that sex selection for non-medical reasons 'would obviously affect the individual family and the

\footnotetext{
${ }^{69}$ HL Deb, Hansard, 28 January 2008, cols 483-484, emphasis supplied.

${ }^{70}$ HL Deb, 28 January 2008, col 484, emphasis supplied.
} 
children involved, and would also have implications for society as a whole' ${ }^{71}$ While it was 'impossible to predict' the effect on the male-to-female ratio in society, 'important social implications' could follow if males were chosen to be the first born and 'there is considerable evidence that the firstborn sibling may enjoy certain advantages over younger siblings' ${ }^{72}$ Sex selection might have 'particular implications for the role of women in society'. ${ }^{73}$ Thus:

[t]hese important considerations make the Inquiry dubious about the use of sex selection techniques on a wide scale, but because of the difficulty of predicting the outcome of any such trend we have not found it possible to make any positive recommendations on this issue. Nevertheless, we consider that the whole question of the acceptability of sex selection should be kept under review. ${ }^{74}$

Other 'societal' harms might include the start of a slippery slope if sex selection for nonmedical reasons was permitted, ${ }^{75}$ one sex being viewed as a 'harmful trait', ${ }^{76}$ gender-role expectations being reinforced, ${ }^{77}$ a consumerist attitude to children developing, or an imbalance in a society's sex ratio thereby being created. ${ }^{78}$

For these concerns to be, legally and/or morally, relied upon, supporting evidence is surely necessary. Indeed, the Science and Technology Committee declared that '[r]eproductive and research freedoms must be balanced against the interests of society but alleged harms to

\footnotetext{
${ }^{71}$ Warnock Report, n 12 above, para 9.11, emphasis supplied.

${ }^{72}$ Ibid.

${ }^{73}$ Ibid.

${ }^{74}$ Ibid.

75 Discussed in, for eg., HFEA, Sex Selection: Choice and Responsibility in Human Reproduction (HFEA: London, 2002) paras 92-95; SD Pattinson, Influencing Traits Before Birth (Ashgate: Aldershot, 2002) Ch 6.

${ }^{76}$ S Pattinson, Medical Law and Ethics (Sweet and Maxwell: London, $4^{\text {th }}$ edn, 2014) 292.

${ }^{77}$ House of Commons, n 24 above, para 135-136.

${ }^{78}$ Noted in, for eg., E Jackson, Medical Law: Text, Cases and Materials (Oxford University Press: Oxford, $3^{\text {rd }}$ edn, 2013) 824-829; J Herring, Medical Law and Ethics (Oxford University Press: Oxford, $5^{\text {th }}$ edn, 2014) 394396; Pattinson, n 77 above, 292-293.
} 
society, too, should be based on evidence' ${ }^{79}$ However, as we have noted above and discuss further in the following section, the HFEA offered limited evidence for its stance against nonmedical sex selection in its 2003 report. $^{80}$ The Committee suggested that the precautionary principle should apply to human reproductive technologies, meaning that 'alleged harm to society or to patients needs to be demonstrated before progress is unduly impeded, ${ }^{81}$ If it cannot be shown that non-medical sex selection is likely to cause serious harm to the welfare of individual children or wider damage to society, then what justified the prohibition on the use of PGD for these reasons? We suggest that fear of a risk of serious harm, as seemingly demonstrated by public opinion, played a significant role.

\section{B. Public Opinion}

As we noted in Part II, during 2005 the Government undertook a public consultation on the 1990 Act and a summary of that consultation was published in March 2006. ${ }^{82}$ The consultation document noted that, as we discuss further below, a MORI survey in 2003 had 'found strong public opposition to sex selection for non-medical reasons' and that the Science and Technology Committee had been unable to justify prohibiting sex selection for family balancing reasons. $^{83}$ The Government thus sought views on sex selection for non-medical reasons and while there were $\underline{535}$ respondents to the consultation in total, no figures are provided regarding responses to each question. ${ }^{84}$ The report on that consultation stated that arguments for and against sex selection were received but that within societies and

\footnotetext{
${ }^{79}$ House of Commons, n 24 above, para 46.

${ }^{80} \mathrm{n} 63$ above.

${ }^{81}$ House of Commons, n 24 above, para 47, emphasis supplied.

${ }^{82}$ DH, n 26 above; People Science and Policy Ltd, Report on the Consultation on the Review of the Human Fertilisation and Embryology Act 1990, prepared for the DH (DH: London, 2006).

${ }^{83} \mathrm{DH}, \mathrm{n} 26$ above, paras 5.30-5.31, emphasis supplied. See House of Commons, n 24 above, para 142, emphasis supplied. Also, Recommendation 30.

${ }^{84}$ People, Science and Policy Ltd, n 83 above, section 1.2.
} 
organisations there was no consensus on sex selection. ${ }^{85}$ Nevertheless, in the White Paper of 2006 it was said that 'it was clear that responses generally favoured measures such as a ban on sex selection of offspring for non-medical reasons', and that '[ $\underline{s] \text { ociety's collective and }}$ considered opinion is the ultimate arbiter of the controls to be applied to the development and use of human reproductive technologies'. ${ }^{86}$ The range of opinions in the consultation on screening and selecting embryos was noted and it was concluded that there was a 'general desire' for the law to be clearer. ${ }^{87}$ As part of this, Parliament was to define the limits or criteria regarding testing embryos, ${ }^{88}$ and:

the Government is persuaded that sex selection for non-medical reasons within treatment services should be prohibited, including for "family balancing". This reflects, in part, the strength of public opinion on this matter that this should not be a matter for choice open to potential parents' ${ }^{89}$

Both the draft bill of May 2007 and the HFE Bill included statutory prohibitions on selecting an embryo on the basis of sex for non-medical reasons, ${ }^{90}$ and the Joint Committee on the May 2007 bill stated that '[s]ome attempts ... have been made to measure public opinion [on sex selection of embryos for non-medical reasons]' and that the Chief Executive of the HFEA had told them that the HFEA had 'found that largely very overwhelmingly the public in this country were opposed to sex selection for non-medical reasons' and that 'it's policy on sex selection has public support on the basis of this public consultation' ${ }^{91}$ The Joint Committee was, however, cautioned by the Royal Society about the use of apparent 'public opinion' in

\footnotetext{
${ }^{85}$ People, Science and Policy Ltd, n 83 above, section 5.6.

${ }^{86} \mathrm{DH}, \mathrm{n} 27$ above, paras 1.11-1.12, emphasis supplied.

${ }^{87} \mathrm{DH}, \mathrm{n} 27$ above, para. 2.42.

${ }^{88}$ Ibid.

${ }^{89} \mathrm{DH}, \mathrm{n} 27$ above, para. 2.47, emphasis supplied.

${ }^{90}$ Human Tissue and Embryos (Draft) Bill, Cm 7087, Sched 2 para $1 \mathrm{ZB}$.

91 Joint Committee, n 29 above, para 17, emphasis supplied.
} 
policy making and the need to ensure that public engagement was 'methodologically rigorous based on principles of effective public engagement and any support material must be scientifically sound', and we consider this further in Part IV. ${ }^{92}$ Nevertheless, the idea that 'the public' supported a ban on sex selection for non-medical reasons was explicitly reiterated in the House of Lords debates on the HFE Bill where Baroness Deech stated that '[t]he public came out very clearly against sex selection for social reasons and that has remained the rule of the [HFEA] and it is in the Bill'. ${ }^{93}$ Furthermore, in the House of Commons Alan Johnson, the sponsor of the Bill, declared that '[f]ollowing the results of the public consultation, the Bill also outlaws sex selection for non-medical reasons' ${ }^{94}$

Given the limited number of respondents to the 2005 consultation on human fertilisation and embryology, it is important to examine claims that 'the public' are not in favour of sex selection for non-medical reasons to determine their validity and reliability. Tracing the history of this claim, the HFEA launched its first public consultation on sex selection in 1993. ${ }^{95}$ The consultation document explained the legality of medical sex selection, the 'ethical issues surrounding the reasons for sex selection', and noted that 'some reasons for sex selection may be more ethically acceptable than others'. ${ }^{96}$ General considerations relating to sex selection were set out, ${ }^{97}$ and three arguments were listed in favour of nonmedical sex selection and four against it. ${ }^{98}$ The only details of the public consultation were published in a letter dated 15 July 1993 from Sir Colin Campbell, the then chair of the HFEA, to the Parliamentary Under-Secretary of State for Health. It stated that the Authority was 'persuaded by the arguments set out in the [public consultation] document against the use of

\footnotetext{
92 Joint Committee, n 29 above, para 20. Also, paras 14-27.

${ }^{93}$ HL Deb, 3 December 2007, col 1587, emphasis supplied.

${ }^{94}$ HC Deb, 12 May 2008, col 1070, emphasis supplied.

${ }^{95}$ HFEA, 'Review of Sex Selection' (2012) < http://www.hfea.gov.uk/517.html> accessed 17/11/15.

${ }^{96}$ HFEA, n 16 above, paras 4, 17 and 16, respectively.

${ }^{97}$ HFEA, n 16 above, paras 18-27.

${ }^{98}$ HFEA, n 16 above, paras 33-39.
} 
sex selection for social reasons, ${ }^{99}$ and all licensed clinics would be written to and 'advised' not to undertake non-medical sex selection, with this advice incorporated into subsequent Codes of Practice. ${ }^{100}$ Public response to the consultation was said to be 'limited' (the number of respondents was not provided), but $\underline{67 \% \text { 'of those respondents who discussed the issues in }}$ general terms' were opposed to sex selection for non-medical reasons. ${ }^{101}$

The HFEA subsequently disclosed that 2,000 copies of the consultation document were issued and $\underline{165}$ responses received. ${ }^{102}$ The most common public concern over non-medical sex selection was reinforcing gender stereotypes to women's disadvantage, with other concerns including 'a "slippery slope” towards selecting the "perfect child”, children being seen as 'consumer goods', and the effect on the family of using the techniques, regardless of success. ${ }^{103}$ The HFEA concluded that 'while the arguments on this issue are complex, the view of the Authority on sex selection for social reasons is strongly supported by the public who responded to our consultation exercise' ${ }^{104}$ Nevertheless, the HFEA would 'be keeping the matter under review in the light of any new information or changes in public opinion'. ${ }^{105}$ Following this consultation, the HFEA's Code of Practice was amended and, as we noted in Part I, the Code has consistently stated that embryos should not be selected on the basis of sex 'for social reasons'. 106

Using PGD to identify embryos with genetic disorders, for medical reasons only, was considered in a joint consultation by the HFEA and the Advisory Committee on Genetic

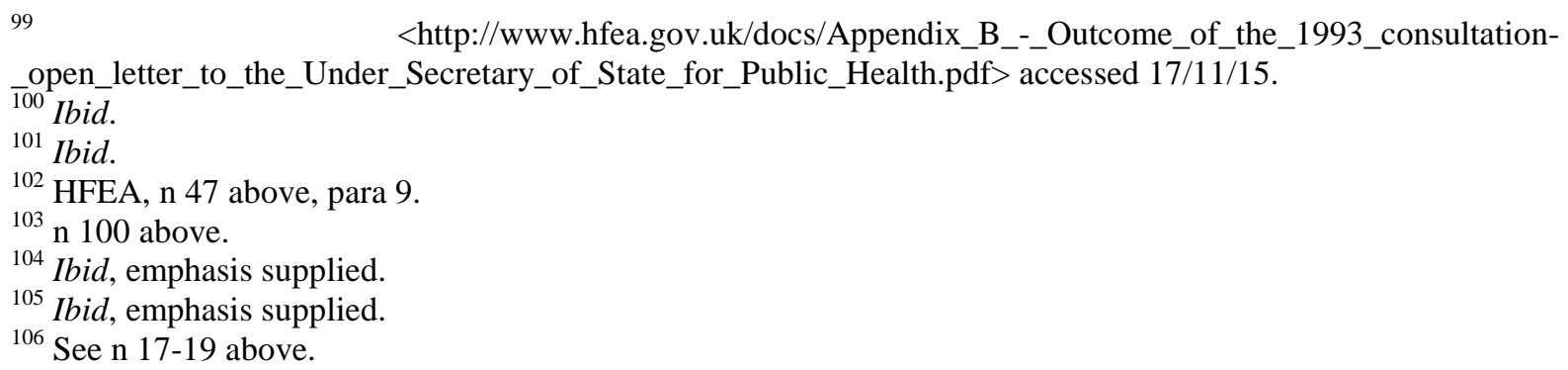


Testing in 1999. ${ }^{107}$ There were 171 responses to this consultation (47 from organisations and 124 individuals) and 88 of 119 respondents (74\%) agreed that PGD should be used to select an embryo on the basis of its sex for 'a limited number of specific serious inherited conditions'. ${ }^{108}$ It was thus recommended that 'PGD should only be available where there is a significant risk of a serious genetic condition being present in the embryo' ${ }^{109}$ Similarly, the Nuffield Council on Bioethics discussed PGD in its 2002 report on genetics and human behaviour, ${ }^{110}$ and recommended that its use continued to be limited to 'serious diseases and disorders' rather than increased to include behavioural or personality traits. ${ }^{111}$ While not specifically considering using sex selection for non-medical reasons, the Council said that 'there seems to be a consensus in clinical genetics and in public opinion against [the] use of PGD ... in order to select babies on the basis of non-clinical characteristics'. ${ }^{112}$ The basis for this statement is unclear, but it may be that more recent claims about public opinion can be traced back to the results of the Government's request, in 2002, for the HFEA to consider sex selection via a number of strands - a scientific report on sex selection techniques, ${ }^{113}$ market research involving a cross section of the public to 'map out their perceptions of the issues [raised by sex selection] and identify the ways in which they resolve potentially conflicting views', ${ }^{114}$ an opinion survey, ${ }^{115}$ a literature review on the ethical and special issues raised by

\footnotetext{
${ }^{107}$ HFEA and Advisory Committee on Genetic Testing, Consultation Document on Preimplantation Genetic Diagnosis (HFEA: London, 1999).

108 HFEA and Human Genetics Commission (HGC), Outcome of the Public Consultation on Preimplantation Genetic Diagnosis (HFEA: London, 2001) para 28, p 12.

${ }^{109}$ HFEA and HGC, n 109 above, Recommendation 11, emphasis supplied.

${ }^{110}$ A consultation paper was issued in 2001 (Nuffield Council on Bioethics, Genetics and Human Behaviour: The Ethical Context (Nuffield Council on Bioethics: London, 2001), and there were 110 responses to it: Nuffield Council on Bioethics, 'External consultation - Public Consultation' $<$ http://nuffieldbioethics.org/project/genetics-behaviour/external-consultation> accessed 17/11/15.

${ }^{111}$ Nuffield Council on Bioethics, Genetics and Human Behaviour: The Ethical Context (Nuffield Council on Bioethics: London, 2002) para 13.78.

112 Nuffield, n 112 above, para 13.65, emphasis supplied. Also, Box 13.3.

${ }^{113}$ L Björndahl and CLR Barratt, Sex Selection; A Survey of Laboratory Methods and Clinical Results (2002) $<$ http://www.hfea.gov.uk/docs/Appendix_C_-_Scientific_and_Technical_Literature_Review.pdf $>$ accessed $17 / 11 / 15$.

114 Counterpoint, Prepared for Human Fertilisation and Embryology Authority, Sex Selection - Policy and Regulatory Review: A Report on the Key Findings from a Qualitative Research Study (2002) 3 $<$ http://www.hfea.gov.uk/docs/Appendix_E_-
} 
sex selection, ${ }^{116}$ and a public consultation document, with sperm sorting its primary focus. ${ }^{117}$ This document set out arguments for and against sex selection, and included comments from participants in the market research.

These results of the consultations were published in 2003. ${ }^{118}$ For the market research, group discussions were held with 12 groups of adults over 18 between 18 June and 16 July 2002 in Birmingham, Belfast, Cardiff, Edinburgh and London. ${ }^{119}$ Participants were not told in advance of the topic for discussion, which was introduced by a moderator who guided the group through the issues raised by the initial question 'what comes to mind when I say "sex selection” to you?' ${ }^{120}$ Reported conclusions included that '[a]lmost no-one was aware of sex selection, for any reason, thus when it was mentioned, respondents immediately imagined sex selection as being for social reasons', but that '[o]nce prompted, respondents tended to argue for the current practice of allowing sex selection because of a genetic disease which affects only one sex'. ${ }^{121}$ Furthermore, 'although they had no idea of how sex selection might be achieved, they all assumed it would involve major intervention' and '[t]heir immediate, or "gut” reactions tended to be fairly strong and usually negative'. ${ }^{122}$ Participants also 'felt that there was a necessary difference between parents trying to avoid suffering which was likely to occur in future children, and parents wanting a specific type of child', ${ }^{123}$ and '[m]ost within the sample felt that, whatever the method used, non-medical reasons, and

_Qualitative_Research_Findings_report_of_research_conducted_by_Counterpoint_(UK)_Ltd.pdf> accessed 17/11/15.

${ }^{115}$ Research conducted for Human Fertilisation and Embryology Authority by MORI, Sex Selection - Public Consultation (2003) <http://www.hfea.gov.uk/docs/Appendix_F.pdf> accessed 17/11/15.

${ }^{116}$ C Waldby, Literature Review and Annotated Bibliography: Social and Ethical Aspects of Sex Selection (2003) <http://www.hfea.gov.uk/docs/Appendix_D_-_Social_and_Ethical_Literature_Review.pdf> accessed 17/11/15.

${ }^{117}$ HFEA, n 76 above. For criticism of this consultation see S Holm, 'Like a frog in boiling water: The public, the HFEA and sex selection' (2004) 12 Health Care Analysis 27.

${ }^{118}$ HFEA, n 47 above. Also, HFEA, Sex Selection: Report Summary (HFEA: London, 2003).

${ }^{119}$ Counterpoint, n 115 above, 6. The methodology is discussed further at 6-11.

${ }^{120}$ Counterpoint, n 115 above, 7.

${ }^{121}$ Counterpoint, n 115 above, 12.

122 Ibid.

${ }^{123}$ Ibid. 
insufficiently serious medical reasons were not grounds to justify sex selection', with nonmedical reasons causing 'major discomfort within the groups'. ${ }^{124}$ Participants requested that 'a reasonable debate ... take place; that the debate has a moral and family dimension, and not simply take place on the question of whether people should have a choice or not', ${ }^{125}$ and it was reported that a 'minority' of the participants (number not stated) thought that as the technology existed and sex selection did no harm, people should have access to it. ${ }^{126}$

Questions on sex selection were also placed on the regular MORI survey of the public (the MORI Omnibus), and 2,165 people over 16 interviewed face-to-face in their homes throughout Britain between 9 and 14 January 2003. ${ }^{127}$ 14\% of the respondents (306/2165) agreed that 'any prospective parent should have the right to choose the sex of their child', $68 \%(1466 / 2165)$ that 'sex selection should be regulated', ${ }^{128}$ and $\underline{65 \%(731 / 1123)}$ that sex selection through testing embryos created outside the body should only be permitted for medical reasons. ${ }^{129} 18 \%(200 / 1123)$ agreed that sex selection should be permitted for ““family balancing” (having a child of a different sex when there are only children of one sex in the family)', and 8\% (85/1123) for 'any social or cultural reason, or reasons of individual choice'. ${ }^{130}$ Despite these apparently clear opinions in favour of regulation and against nonmedical sex selection, only 21\% (465/2165) correctly identified that sex selection involved choosing a baby's sex and there was general ignorance about the possibility of sex selection, ${ }^{131}$ although $80 \%$ of respondents (1722/2165) subsequently identified reasons why couples might want to choose the sex of their baby. ${ }^{132}$ The disparity between the

\footnotetext{
${ }^{124}$ Counterpoint, n 115 above, 13, emphasis supplied.

125 Counterpoint, n 115 above, 14.

${ }^{126}$ Counterpoint, n 115 above, 15, emphasis supplied.

${ }^{127}$ MORI, n 116 above, 3 and 6.

128 MORI, n 116 above, Q3.

129 MORI, n 116 above, Q5.

130 Ibid.

${ }^{131}$ MORI, n 116 above, Q1.

${ }^{132}$ MORI, n 116 above, Q2.
} 
respondents' limited knowledge of sex selection and their predominantly negative responses to it are interesting, and the value of the research would undoubtedly have been strengthened if information on the technology had been provided and the questions asked again to determine whether that altered or affected their opinions. Without such, the allegation that views were sought from an uninformed selection of the public is hard to refute. Nevertheless, Suzi Leather, the then chair of the HFEA, declared that '[o]ur survey of a representative sample of the population clearly indicates that there is a general moral consensus in the United Kingdom against parents selecting the sex of their children for primarily personal reasons like "family balancing", 133

Finally, the 2002 public consultation document was sent to 248 organisations and the public could write and request a copy of it or download it from the HFEA's website. $\underline{641}$ valid responses were received (66 from organisations and 575 from individuals), ${ }^{134}$ but not all respondents answered the eight questions set out in the document. Of those who did, $\underline{83 \%}$ (489/589) disagreed that PGD should be permitted for selecting sex for non-medical reasons, ${ }^{135}$ 83\% (489/589) also disagreed that sex selection by sperm sorting or PGD should be permitted 'for non-medical reasons when a family has at least two children of one sex and none of the other sex' (family balancing), ${ }^{136}$ and $\underline{85 \%(501 / 589) \text { disagreed that sex selection }}$ by sperm sorting or PGD should be permitted for 'non-medical reasons other than family balancing'. ${ }^{137}$ Following these consultations and surveys, the HFEA concluded that '[t]he strength of opposition to sex selection for any but serious medical reasons revealed by this consultation is clear', ${ }^{138}$ there was no need to review the permissibility of sex selection only

\footnotetext{
${ }^{133}$ HFEA, n 47 above, Chair's Foreword, emphasis supplied.

${ }^{134}$ HFEA, $n 47$ above, 15.

${ }^{135}$ HFEA, n 47 above, Statement 5, p 24.

${ }^{136}$ HFEA, n 47 above, Statement 7, p 25.

${ }^{137}$ HFEA, n 47 above, Statement 8.

${ }^{138}$ HFEA, n 47 above, para 97, emphasis supplied.
} 
for medical reasons, and this was 'supported by a clear majority of those in the representative national sample polled by MORI'. ${ }^{139}$ Nevertheless, with regards to the public's response to the 2002 consultation, the HFEA admitted that:

[a]lthough the consultation was not a scientifically robust way of sampling representative public opinion on this subject, it is valuable to note the views of those who were sufficiently interested in the issues raised to respond. Many wrote at considerable length to explain why they were answering as they did, and their explanations have helped to inform the development of our conclusions. ${ }^{140}$

Furthermore:

[i]n reaching a decision we have been particularly influenced by the considerations ... relating to ... the welfare of the child ..., and by the quantitative strength of views from the representative sample polled by MORI and the force of opinions expressed by respondents to our consultation. These show that there is very widespread hostility to the use of sex selection for non-medical reasons. ${ }^{141}$

It may have been these consultations and surveys that the Government was referring to in its response to the Science and Technology Committee's 2005 report, when it said that it was 'aware of public concerns about the possible use of sex selection techniques for social reasons' and that it, thus, had 'no plans ... to allow sex selection other than for compelling medical reasons'. ${ }^{142}$ The Government also said that it would 'seek wider public views on

\footnotetext{
${ }^{139}$ HFEA, n 47 above, para 100.

${ }^{140}$ HFEA, n 47 above, para 50, emphasis supplied.

${ }^{141}$ HFEA, n 47 above, para 147, emphasis supplied.

${ }^{142}$ HM Government, n 25 above, para 45, response to Recommendations 29 and 30, emphasis supplied.
} 
whether sex selection for family balancing purposes should be permitted, as recommended by the Committee', ${ }^{143}$ and we discussed the most recent consultation at the start of this section.

It is clear that despite consistent and repeated claims of overwhelming public opinion against using PGD for non-medical reasons, the validity of these claims are tenuous, to say the least. That these have been used to support a criminal prohibition on such use raises, we suggest, a number of issues which require consideration before 'public opinion' is used again as the basis for regulation.

\section{PROBLEMS WITH BASING REGULATION ON PUBLIC OPINION}

In 2005 the Science and Technology Committee noted some of the concerns about how public opinions were used (and were seen to be used) as the basis for policy. ${ }^{144}$ Some of the practical problems of conducting public consultations should be clear from the above. These include recruiting an appropriate number of participants, and ensuring that they have some understanding of the issues and their complexity prior to responding to questionnaires or being involved in discussions or interviews. Beyond this, we suggest that there are other problems with regulating on the basis of public opinion. As it appears that the majority of the respondents to the public consultations were against allowing PGD to be used to select an embryo on the basis of its sex for non-medical reasons, it might seem that allowing public opinion to influence regulation was fairly straightforward. But what if a consensus was not found? And if regulation is to be based on public opinion regarding non-medical sex selection, then why is such opinion not sought or the basis of regulation on other controversial and contested issues, such as embryo experimentation or funding fertility

\footnotetext{
${ }^{143} \mathrm{Ibid}$.

${ }^{144}$ House of Commons, n 24 above, paras 360-361.
} 
services at all? This might be because even if we provided information about these issues in as balanced a way as possible, consensus is unlikely because of the very nature of the issues themselves. Indeed, a common characteristic of these issues is that they polarise debates. But if public opinion is to be the foundation of regulation and public opinion does not provide us with a clear direction, then what are we to do? A compromise may be possible based on the results of public consultation, but it is difficult to understand what a true compromise, where both sides gain and/or loose in roughly equal amounts, on ethical issues such as these would look like. Indeed, it is difficult to see how a true compromise position can be achieved on ethical issues where views are polarised. Given this, how do, and should, we value the views of the people when disagreement on these issues is so divided?

Regardless of these concerns, the HFEA's policy on not using PGD to select sex for nonmedical reasons, and the subsequent incorporation of this into legislation, appears to have been, at the very least, influenced by (supposed) 'public' opinion on this issue. Indeed, the HFEA stated that:

By itself this finding [of widespread hostility to permitting sex selection for nonmedical reasons] is not decisive; the fact that a proposed policy is widely held to be unacceptable does not show that it is wrong. But there would need to be substantial demonstrable benefits of such a policy if the state were to challenge the public consensus on this issue. In our view the likely benefit of permitting sex selection for non-medical reasons in the UK are at best debatable and certainly not great enough to sustain a policy to which the great majority of the public are strongly opposed. ${ }^{145}$

${ }^{145}$ HFEA, n 47 above, para 147, emphasis supplied. 
The argument appears to be that while there may not be evidence that using PGD to select an embryo of a particular sex for non-medical reasons harms the child who will be born or their siblings (and so is morally wrong), the benefits of permitting such use is similarly limited. This quote suggests that the HFEA weighed the harms that may be accrued by offending the public, whatever they might be, against the benefits that may follow from allowing parents to select embryos of a particular sex for non-medical reasons, and determined that the former outweighed the latter. However, as we have discussed in Part IIIA, when the benefits of using PGD for non-medical sex selection are examined, we see that they are, in fact, similar to those of using it for medical reasons and also for other assisted reproductive procedures, including IVF. This is because they all allow would-be parents the chance of having a child with characteristics they desire, whether that be a child they are genetically connected to, or one without a particular condition, or a child of a particular sex.

In the Science and Technology Committee's report the fact that the validity of the data gathered by the HFEA in support of its conclusions on sex selection had been questioned was noted, but it was said that:

even if the HFEA exaggerates the public's hostility to sex selection for social reasons, we have little reason to doubt that a majority of the British public oppose it. Professor Tom Shakespeare from Newcastle University has provided confirmation of this from his own research. Nevertheless, we do not 'see this as adequate grounds for prohibition' ${ }^{146}$

\footnotetext{
${ }^{146}$ House of Commons, n 24 above, para 142, reference removed, emphasis supplied.
} 
This quote raises two points which deserve further consideration and are relevant to the use of public opinion generally and specifically in relation to sex selection. The first relates to the matter evidence. Tom Shakespeare told the Committee that '[i]n our social research into "ordinary ethics", all lay respondents were opposed to social sex selection, and this evidence is born out by other surveys, including the HFEA research'. ${ }^{147}$ He did not, however, provide any further information regarding this research nor the other evidence he referred to. The second point relates to the idea that public opinion is not an 'adequate ground' for prohibiting parents from selecting embryos of a particular sex for non-medical reasons. Along with our general comments at the start of this section on using public opinion as the foundation for regulation, John Harris has argued that we have:

some reason to be cautious about claims to the effect that forms of public consultation have revealed the moral attitudes or values of the public, and that these must both be respected and inform public decision-making. If what is informing public decisionmaking is a collection of recorded prejudices or evidence of slavish and uncritical adherence to a sectarian normative system, then perhaps the respectability, if not the authenticity, of the voice of the people requires challenge rather than faithful reporting and incorporation into the decision-making process. ${ }^{148}$

If we rely on public opinion in policy making then we must accept that many of those who respond to public consultations are likely to provide an intuitive 'gut' reaction to the issue. Such reactions may be based on false information, prejudice and fear. They may also be inconsistent with some of their other views and, therefore, difficult to defend or justify. The

\footnotetext{
${ }^{147}$ House of Commons Science and Technology Committee, Human Reproductive Technology and the Law, Fifth Report of Session 2004-05 (2005), Volume II, HC 7-I, Appendix 65, Ev 362, Dr Tom Shakespeare, emphasis supplied.

${ }_{148}$ J Harris, 'Introduction: The Importance of Bioethics' in J Harris (ed.) Bioethics (Oxford University Press: Oxford, 2001) 12.
} 
Joint Committee on the draft Bill of May 2007 recognised some of the problems of relying on public consultations, and said that '[r]esponses to public consultations often come from those with strong views which may not be representative of those held by the general public. Those who reply to public consultations are by their nature self-selecting'. ${ }^{149}$

There are limits to what public consultations can do and the use to which the results of them, and so 'public opinion', should be put. Indeed, the Joint Committee was 'concerned by the $\underline{\text { unsubstantiated claims made about public opinion and public support and by the lack of }}$ evidence provided' and we agree that '[w]here organisations claim to speak on behalf of the public, they should have a proper research basis to do so that is capable of scrutiny'. ${ }^{150}$ Public consultation may enable us to find out what some people's gut reaction to particular ethical issues are, but it will not necessarily help us to determine the moral acceptability of a practice nor how we should regulate (or not) it.

\section{CONCLUDING REMARKS}

The preferred way to determine how we should regulate practices such as non-medical sex selection is to examine the evidence and provide a reasoned, consistent and defendable position, and it was on this basis that the Science and Technology Committee, in 2005, concluded that it could 'find no adequate justification for prohibiting the use of sex selection for family balancing' ${ }^{151}$ However, even though there was no evidence that using PGD to select an embryo on the basis of its sex for non-medical reasons alone will harm anyone, the amendments to the 1990 Act introduced by the 2008 Act make it a criminal offence to use PGD for such reasons. This provision placed on a statutory footing HFEA policy since 1995,

\footnotetext{
149 Joint Committee, n 29 above, para 21.

150 Joint Committee, n 29 above, para 22, emphasis supplied.

151 Joint Committee, n 29 above, Recommendation 30.
} 
policy which has consistently been said to be based on fear harm, the idea that the benefits of such selection are significant enough to outweigh these unsubstantiated harms, and that this position is supported by public opinion. Although the Science and Technology Committee shone a spotlight on the fallacies of this position, this was ignored by a Government seemingly convinced of the merits and popularity of stance.

Using public opinion to guide regulation is difficult and it is hard to formulate questions that do not lead opinion in one direction or another. Using public opinion as the basis for regulation may result in contradictory regulation or regulation that is inconsistent and unstable and it may need frequent updating. Public opinion changes over time as social norms evolve and as the public becomes more familiar with, and, possibly, more accepting of certain practices. Relying on public opinion for guidance on regulation is, at the very least, practically problematic. As a result, there are few calls for regulation to be informed in this way. The classic example here is that although the majority of respondents to polls are in favour of capital punishment for some crimes, there has never been a serious attempt to allow public opinion to influence the legal stance on this form of punishment in England and Wales. $^{152}$ While public opinion should not be dismissed, it is difficult to see why public opinion should be allowed such an influence in some situations, such as non-medical sex selection, but not in others. This is particularly troubling where this results in policy which is inconsistent with the approach to other comparable practices.

A reasonable and defendable position on sex selection is required and a consistent position is needed which is based on clear and explicit foundations. This will help guide us when we are faced with new challenges in this area. The position should be as consistent as possible with

\footnotetext{
152 UK Polling Report, 'Public Opinion on the Death Penalty' 30 July 2011 <http://ukpollingreport.co.uk/blog/archives/3802> accessed 17/11/15.
} 
other regulation and policies in the area, so that that regulation is 'more stable' and less likely to be amended or repealed. This was one of the aims of the amendments introduced by the $2008 \mathrm{Act}^{153}$ and, in general, this is what was achieved. Some of those amendments moved the original 1990 Act away from judgements about individuals' abilities to be good parents towards an assumption to treat unless there was evidence of serious harm to the resultant child. This is, essentially, an adoption of a classic harm principle approach to legislation that recognises the importance of reproductive autonomy and reproductive opportunities. In doing so, it moves away from the idea that children who are born into the only conditions they can be born into, and who are likely to value their lives as much as any of us, are harmed by this 'suboptimal' but still worthwhile existence.

But this general approach stops when we look at using PGD to identify the sex of embryos for non-medical reasons. Although it is admitted that there is no evidence that children born for these reasons will suffer serious harm, this practice is not only prohibited but is criminalised on the basis that there is not enough evidence of the benefits in order to outweigh the supposed public distaste for sex selection for these reasons. We suggest that it is a mistake to distinguish between selecting an embryo on the basis of its sex for nonmedical reasons from other assisted reproductive techniques because they are comparable. Medical sex selection, and IVF more generally, are often used to create a child with particular characteristics, such as one who is free of a sex linked disorder or who is genetically related to their parents. The motivation, in most cases, is to be a parent to a child with these particular characteristics, rather than pure concern for the welfare of the resultant child.

\footnotetext{
153 'The Act requires the HFEA to maintain a statement of the general principles that we consider should be followed in carrying out activities covered by the Act. The principles: summarise the key behaviours and outcomes we expect licensed centres to demonstrate, and communicate the areas of compliance we regard as important. The principles inform every part of the Code. Each guidance note is linked to one or more of the principles and they should be read together': HFEA, 'User Guide to the Code, Version 2' <http://www.hfea.gov.uk/333.html> accessed 17/11/15.
} 
Indeed, in most cases, even in medical sex selection cases, the disorder that we are trying to avoid is not one that would 'blight' that child's life and make that life not worthwhile. We would expect a child who is born with most of these disorders to have a challenged but still worthwhile life, a life that they would be likely to value as much as the next child. Given this, it is not as easy to distinguish between using PGD to select embryos of a specific sex for medical and non-medical reasons as might first be presumed.

The 2008 Acts' amendments to the 1990 Act, in general, introduced a clear moral stance on the regulation of assisted reproduction, with an explicit foundation in the harm principle and a commitment to reproductive autonomy. Yet, non-medical sex selection was singled out for different treatment. As a result, we have a general approach to regulation which is based on reason, evidence and critical thinking about the issues in hand, with one issue treated differently without good reason. Here, the cry of 'it's what the public wants' has been used to endorse the prohibition on using PGD to select an embryo on the basis of its sex for nonmedical reasons only. The singling out of non-medical sex selection is both curious and indefensible. We hope that the use public opinion as the basis for regulation is carefully considered and that it remains the exception rather than the rule. 